\title{
The applicable law in the Caribbean Single Market
}

\author{
by Rolston Nelson
}

$\mathrm{T}$ he conundrum of the regional court is that while it is a supranational body created by international agreements and applying international law, it purports to prescribe a uniform local law for the limited geographic area of its jurisdiction based on considerations legal and economic peculiar to that geographic area.

Regional courts set up under regional trade agreements aim to affect the internal trade laws of a group of states by making them uniform and consistent throughout the region. Thus, regional courts will develop a legal régime peculiar to those states that can hardly be said to be of universal application to all states as international law.

Regional courts of justice exist as offshoots of regional economic communities. But not all regional economic communities have a court of justice. The North American Free Trade Agreement (NAFTA) and the Association of Southeast Asian Nations (ASEAN) have none. But the European Union, the Caribbean Community (CARICOM), the Andean Community and the Central American Integration System have courts of justice. Since several regional courts of justice are all modelled on the European Court of Justice, it is convenient to compare the Caribbean Court of Justice and the European Court of Justice to discover what law applies to regional courts of justice.

\section{BACKGROUND TO CARIBBEAN ECONOMIC INTEGRATION}

The CARICOM Single Market and Economy ("CSME") was established by the Revised Treaty of Chaguaramas ("the Revised Treaty"), which the Caribbean Court of Justice (hereinafter referred to as "the Caribbean Court") is required by Article 211 of the Revised Treaty to interpret and apply. The Caribbean Court is not a national court, and it is not an institution of the Caribbean Community.

The original Treaty of Chaguaramas ("the original Treaty") established the Caribbean Community and a Common Market. It was signed at Chaguaramas, Trinidad on July 4, 1973. On July 5, 2001 in Nassau, Bahamas the original Treaty was amended by nine protocols. I refer to the amended Treaty as the Revised Treaty. The purpose of the Revised Treaty, as set out in an extensive 28 paragraph preamble, is to create one single internal market among the Member States and to forge a new Caribbean economy and purpose of economic integration is a new Caribbean economy based on exports that are internationally competitive, a pooling of resources and functional cooperation generally. Monetary union is envisaged as well convergence of macro-economic performance and policies through harmonisation of monetary and fiscal policies.

On February 14, 2001 in Barbados some Member States signed the Agreement establishing the Caribbean Court ("the Agreement"), giving the court an original jurisdiction to interpret and apply the Revised Treaty. The contracting parties to the Agreement recognise the jurisdiction of the court as compulsory, ipso facto and without special agreement: see Article XVI of the Agreement, which has an almost verbatim counterpart in Article 216 of the Revised Treaty.

\section{THE REVISED TREATY IN INTERNATIONAL LAW}

There is no doubt that the Caribbean Community (CARICOM) like the European Union, is a creature of international law. International law principally consists of:

(a) customary international law, ie legally binding rules that have developed between states over time and

(b) the law of treaties, which deals with the principles affecting the making of international agreements.

Article XVI of the Agreement and Article 216 of the Revised Treaty constitute an acceptance or consent ante hoc to the jurisdiction of the Caribbean Court on the international plane. These provisions are similar to the optional clause in Article 36(2) of the Statute of the International Court of Justice. No other international tribunal than the Caribbean Court may be called upon to adjudicate a dispute between Member States or between Member States and the Community or between a CARICOM individual and either a Member State or the Community. However, the introduction of the word "exclusive" in Article 211 (jurisdiction of the Caribbean Court in contentious proceedings) has created the impression that on the municipal plane national courts have no jurisdiction to entertain questions concerning the interpretation and application of the Revised Treaty. "Exclusive" in Article 211 emphasises the mandatory nature of the Caribbean Court's jurisdiction on the 
international plane. Indeed Article 214 of the Revised Treaty (referral to the Caribbean Court) envisages that decisions on issues of fact in relation to the reference remain squarely in the hands of the national court. Article 177 of the EC Treaty, which contained a similar provision for references by a national court to the ECJ has been given a similar interpretation: see Practice Direction - References to the European Court. Thus, there exists side by side with the Caribbean Court's jurisdiction on the international plane a parallel but restricted jurisdiction at the municipal level.

Regional trade agreements, though born out of agreements in international law, are normative and thus create regional or Community law that is different from international law. I refer to two ways in which Community law is different from international law. In the first place, regional economic communities can confer rights and impose obligations on Community nationals, although that is not normally the case in international law. Secondly, in international law a breach of treaty obligations is normally a matter between the contracting states, and enforcement of such obligations is hardly ever by individuals or entities against a contracting state or their own state and rarely before an international court with compulsory jurisdiction or before a national court. Thus, I accept that regional integration treaties create a new legal system, but recognize that the new system is derivative of international law. Within the Community, a new international legal order of international law is created, but outside the Community international law prevails, as for example, as regards the Community's relations with third parties: see case 10/61 Italy ${ }_{\mathrm{V}}$ Commission [1962] ECR 1, 10.

\section{EVOLUTION TO A NEW COMMUNITY LEGAL SYSTEM}

International regional trade agreements are at the outset governed by international law, and, as stated above, particularly by customary international law relating to treaties. It is generally accepted that the Vienna Convention on the Law of Treaties 1969 ("the Vienna Convention") codifies that customary law. Thus, the interpretation of a regional trade agreement is governed by Articles 31-33 of the Vienna Convention.

According to Article 31(1) of the Vienna Convention, a treaty has to be interpreted in its context and in the light of the object and purpose of the treaty. By Article 31(2) the context includes the text of the treaty including its preamble and annexes.

In construing the Revised Treaty one has to bear in mind that the revision took place in the context of "the commitment to deepening regional economic integration through the establishment of the CARICOM Single Market and Economy": see the first paragraph of the Preamble.

In addition to the clearly articulated objective of economic integration, the Revised Treaty envisages a role for Community nationals in the integration movement.
Article 222 of the Revised Treaty (locus standi of private entities) provides for private party litigation against a Member State or the Community with respect to rights or benefits conferred on Community nationals.

Further, Article 214 makes it mandatory for a national court or tribunal to refer a question concerning the interpretation or application of the Revised Treaty to the Caribbean Court, if the resolution of that question is necessary "to enable it to deliver judgment." The parties before the national court may include private entities or individuals against a Member State or Member States against one another.

In the well-known ECJ case of NV Algemene Transport-en Expeditie Onderneming van Gend en Loos $v$ Nederlandse Administratie der Belastingen [1963] ECR 1 ("Van Gend en Loos") the ECJ noted the stated objective of economic integration in the EEC Treaty and the indications in the preliminary procedure that nationals were to be involved and participate in the integration process. These considerations led the Caribbean Court to the conclusion that the EEC Treaty, which had been created by international law, was more than just a pact between states, but was an agreement from which individuals and private entities could derive rights. That was the foundation of the conclusion of the ECJ in Van Gend en Loos that "the Community constitutes a new legal order of international law for the benefit of which the states have limited their sovereign rights, albeit within limited fields and the subjects of which comprise not only Member States but also their nationals." The phrase "a new legal order of international law" was modified in Case 6/64 Costa v ENEL [1964] ECR 585, to "its own legal system". Later in Case 294/83 Parti écologiste 'Les Verts' v European Parliament [1986] ECR 1339 the EEC Treaty is described as "the basic constitutional charter." In an opinion on the draft agreement creating the European Economic Area, Opinion 1/91 [1991] ECR I-6079, para 1 the Caribbean Court described the ECJ Treaty in these terms:

“.... The EEC Treaty, albeit concluded in the form of an international agreement, nonetheless constitutes the constitutional charter of a Community based on the rule of law. As the Court of Justice has consistently held, the Community treaties established a new legal order for the benefit of which the States have limited their sovereign rights..."

Similarly in relation to the Revised Treaty, the Caribbean Court of Justice has held that evolving from the international agreement of the Revised Treaty was a new regional legal order based on the rule of law. In TCL $v$ Caribbean Community [2009] 2 CCJ 2 (OJ) the court said this:

\footnotetext{
"By signing and ratifying the Revised Treaty and thereby conferring on this Court ipso facto a compulsory and exclusive jurisdiction to hear and determine disputes concerning the interpretation and application of the Revised Treaty, the Member States transformed the erstwhile voluntary arrangements in CARICOM into a rule-based system, thus
} 
creating and accepting a regional system under the rule of law. A challenge by a private party to decisions of the Community is therefore not only not precluded, but is a manifestation of such a system... The rule of law brings with it legal certainty and protection of rights of states and individuals alike, but at the same time of necessity it creates legal accountability."

The new Community legal system comprises the prescriptive rules laid down by the Revised Treaty and the legal rules which the Caribbean Court pronounces in its rulings and judgments. Thus, international law has facilitated the consensual agreement of states to create a new legal system and to displace customary international law in the areas covered by the Revised Treaty. In so far as the Revised Treaty is silent or the language is vague, the judges must speak and clarify. In Bulmer Ltd v Bollinger SA [1974] 1 Ch 401, 425 Lord Denning MR described the EEC Treaty in language which is appropriate to the Revised Treaty: "All the way through the Treaty there are gaps and lacunae. These have to be filled in by the judges ..." In filling those gaps or lacunae, the court will have to apply "such rules of international law as may be applicable" in accordance with Article 217 of the Revised Treaty. Among such rules of international law will be "the general principles of law" derived from a comparative study of all or most of the legal systems of the Member States.

Notwithstanding the fact that both under the Revised Treaty and the EEC Treaty, there emerged a separate legal system of Community law, there are important differences between the European and Caribbean treaties. In the Caribbean Community legal system, no community organisation has power to issue subsidiary legislation. There are no regulations or directives to bind Member States directly, ie in their national legal systems. There must be the intervention of the constitutional procedures of Member States in order for decisions of organs and bodies of Community organisations to create rights and obligations for nationals of Member States, as Article 240 expressly provides. Further, there is no central body, similar to the European Commission, with power to impose and enforce economic integration by direct legislation or by orders for the harmonisation of laws and procedures, or to impose sanctions in the event of noncompliance with Community law.

It is to be noted that the Caribbean Court stresses the effect of the regional treaty provisions among sovereign states was to create a régime which required compliance by states with the obligations created in the treaty. Lord Bingham of Cornhill made the same point in his lecture on "The Rule of Law" delivered at the Centre for Public Law of the University of Cambridge on November 16, 2006:

“... the existing principle of the rule of law requires compliance by the state with its obligations in international law, the law which whether deriving from treaty or international custom and practice governs the conduct of nations."

\section{THE COMMUNITY LEGAL SYSTEM ABND THE NATIONAL LEGAL SYSTEM}

In the context of the Caribbean Community, the treaty provisions may confer rights and obligations on individuals and entities within a Member State and within the sphere of application of Community law. Those Community rights and obligations are not only theoretically part of the law of the land but have actually been adopted as part of the law of the land. Individuals and entities may therefore invoke those rights and obligations before the courts subject to the principle that the final authority on the interpretation and application of Community law is the Caribbean Court of Justice.

If the Caribbean Community legal system is a separate legal system from the international legal system created by the Revised Treaty, an issue also arises as to the relationship between the Community legal system and the national legal system. Essentially, the question is whether provisions of the Revised Treaty have legal effect within the domestic legal system of Member States. I here refer to their legal effect before the national courts.

There are two legal traditions within the Caribbean Community: the civil law system and the common law system. Broadly speaking, one might describe the civil law tradition as "monist" in the sense that international law and domestic law are one system, and the common law tradition as "dualist" in the sense that international law and domestic law are separate systems. In the dualist system, international law has to be incorporated domestically before it has any domestic effect: see AttorneyGeneral $v$ Joseph and Boyce (2006) 69 WIR 104 at [55] and R $\checkmark$ Secretary of State for the Home Department ex parte Brind [1991] AC 696; Asfaw v R [2008] 1 AC 1061 at [29].

However, the distinction between the monist and dualist approaches to the relationship between international law and domestic law requires careful analysis. Under both the monist and the dualist approaches the basic rule is that the application of treaties in domestic law is governed by a rule of domestic law. But those rules of domestic law vary and are not cut and dried.

In countries such as Belgium, France, the Netherlands and the United States a treaty which has been approved by the state and which has entered into force on the international plane automatically becomes part of the law of the state without any separate act of "incorporation" or "transformation" being required.

In states such as Germany and Italy (commonly regarded as "dualist" states) a treaty must have parliamentary approval. Once parliamentary approval is granted the treaty automatically becomes part of the law of the land.

Nonetheless, in Belgium commercial treaties and those which might affect the state or become binding on certain Belgians must have parliamentary approval before they have legal effect in Belgium: see Article 68(2) of the Belgian Constitution. 
In France, the constitution provides that certain categories of treaties may only be ratified or approved by way of legislation. In the Netherlands, Article 91(1) of the constitution provides that "The Kingdom shall not be bound by treaties ... without the prior approval of the States - General." It also provides that the cases in which approval is not required shall be specified by statute.

The preceding analysis leads to the conclusion that the manner in which a treaty may be given effect to in domestic law may differ according to the specific requirements of domestic law. Indeed, even in the United Kingdom it would not be entirely correct to say that an unincorporated treaty has no effect in domestic law. The courts have recourse to unincorporated treaties. Such treaties may be considered where the legislation is ambiguous, in which case courts will construe a legal provision in a manner that is consistent with the international obligations of the state.

I conclude therefore that merely to label the common law Member States as dualist and Suriname and Haiti as monist does not assist substantially in discovering whether treaty provisions have a direct effect in domestic law in the Caribbean Community, or in regional courts generally.

In the Caribbean Community, the problem of whether treaty provisions conferring rights on individuals and entities have passed into domestic law does not turn on the distinction between monism and dualism since parliamentary approval for the Revised Treaty has been obtained in all the Member States except the Bahamas and Montserrat, the latter not being members of the single market. By contrast in the European Community under the EEC Treaty and the EC Treaty the direct effect of Treaty provisions and subsidiary legislation was automatic regardless of their legal position on incorporation of treaties into the national legal order. This was one of the novel features of Van Gend en Loos. The prohibition against new or increased duties on imports or exports or charges with equivalent effect was "a clear and unconditional prohibition" which did not contemplate "any legislative intervention on the part of the states."

In relation to the common law countries in the Caribbean, the method of incorporation has been to pass an Act of Parliament with the Revised Treaty scheduled thereto and for the Act to state that the Revised Treaty shall have the force of law. A treaty so incorporated becomes part of the law of the land. Thus, in several territories, common law as well as civil law Member States have made the Revised Treaty part of their law. The consequence of the Revised Treaty becoming national law must be that disputes arising out the Revised Treaty are cognizable before the national courts. However, Article 211 of the Revised Treaty accords "compulsory and exclusive" jurisdiction in such matters to the Caribbean Court on the international plane. As indicated above the word "exclusive" refers to adjudication on the international plane. A national court has jurisdiction over an issue of the application and interpretation subject to the limits set out in Article 214 of the Revised Treaty (referral to the Caribbean Court)

\section{REFERENCE TO THE CARIBBEAN COURT AND THE NATIONAL LEGAL SYSTEM}

Article 214 mandates a national court or tribunal to refer a question as to the interpretation or application of the Revised Treaty to the Caribbean Court if the resolution of that question is "necessary to enable it to deliver judgment." The EEC Treaty contains a similar provision in Article 177, later Article 234 of the EC Treaty.

Article 214 allows the national court the discretion to decide when a reference is necessary. Nonetheless, there may be good reasons why no ruling may be necessary. One such reason may be that the Caribbean Court has already decided the point. In Cases 26-30/62 Da Costa V Nederlandse Belastingadministratie [1963] ECR 31 the European Court of Justice did not entertain a preliminary reference since the point at issue had already been determined in Van Gend en Loos (supra). Similarly, previous decisions of the Caribbean Court may have dealt with the point of law, though the questions at issue were not identical.

Another doctrine of the European Court of Justice that ought to be useful is the acte clair principle, whereby if a national court considers the answer to the problem is so clear, it may refuse to make a reference: see CILFIT v Ministry of Health (supra) where the ECJ said:

\footnotetext{
"16. Finally the correct application of Community law may

be so obvious as to leave no reasonable doubt as to the

manner in which the question raised is to be resolved."
}

The principles to be derived from the cases above cited suggest the national courts should become an integral part of Community law. Where there is Community precedent national courts might deal with the matter. Equally, where the doctrine of acte clair applied the national courts may not refer a matter. In all other cases, the national courts may refer an issue of treaty interpretation or application to the Caribbean Court. The effect of the use of the reference procedure in Article 214 of the Revised Treaty in this way would be (1) to build a system of precedent in which the rulings of the court are binding; (2) to involve individuals and entities in the national courts in Community law.

The allocation of a greater role to national courts in Community law is not to ignore the fact that under the reference procedure in Article 214 and in all matters of Community law, the Caribbean Court of Justice is the final authoritative voice. Where the national courts are wrong or are doubtful, the Caribbean court will pronounce finally. The court's role is to promote uniformity and consistency in decisions across the Caribbean Community. 


\section{COMMUNITY LAW AND NATIONAL LAW - THE ISSUE OF PRIMACY}

The experience of the most established regional court, the European Court of Justice, suggests that there are two main pillars of the Community legal system: the doctrine of direct effect earlier discussed and the doctrine of supremacy of Community law.

In areas within the competence of the Caribbean Court of Justice, Community law must prevail over national law. A former judge of the European Court of Justice, Pierre Pescatore, put the matter thus:

"Community law holds within itself an existential necessity for supremacy. If it is not capable in all circumstances of taking precedence over national law, it is ineffective and, to that extent non-existent."

Although the proposition advanced by Judge Pescatore seems compelling in that it is a necessary concomitant of uniform application of Community law, it conceals serious difficulties for the common law countries of the Caribbean Community. Chief among them are inconsistencies between Community law and earlier or later national legislation and between Community law and constitutional provisions. For example, it is common in Caribbean constitutions to find a supreme law clause which nullifies all other laws to the extent of the inconsistency with the constitution. Could a Revised Treaty provision or a Community act be challenged on the ground that it is unconstitutional? Would a Member State be able to deny social and economic rights deriving from the Revised Treaty, such as the right without discrimination to healthcare, school places for children or scholarships (now reserved only to nationals) on the ground that such rights are not recognized by the constitution?

In Costa v ENEL (supra) the European Court of Justice ruled that the supremacy of Community law was a general principle that could not be overridden by domestic legal provisions. Costa was a shareholder in Edison Volta, one of the companies affected by the nationalisation of the production and distribution of electricity. The Italian Government transferred the assets of the nationalised companies to a state-owned company, ENEL. Costa contended that the nationalisation law contravened several EEC Treaty provisions: Article 93 (state aids), Article 102 (distortion of competition), Article 37 (state undertakings) among others. Costa had received an electricity bill from ENEL and went to the Giudice Conciliatore, who referred the matter in two directions - (1) to the Italian Constitutional Court and (2) to the European Court of Justice.

At the time the EEC Treaty had been ratified in Italy by an ordinary law, which could not derogate from the constitution. The Italian court held that the later nationalisation law, to the extent it was inconsistent with the law ratifying the Treaty of Rome, would repeal the earlier law.
The European Court of Justice on the other hand held that the Treaty of Rome ("the EEC Treaty") took precedence over the nationalisation law. Community law had to prevail for the following reasons: (1) the special and original nature of Community law as an independent source of law; (2) acceptance of the new legal system by the Member States on a basis of reciprocity; (3) the transfer of rights and obligations to the Community resulting in a permanent limitation of their sovereignty; (4) a unilateral repudiation of the Treaty was incompatible with the concept of Community and must be rejected.

In Case 11/70 Internationale Handelsgesellschaft (1972) 11 CMLR 255 the claimant argued that a Community regulation was contrary to the principles of freedom of disposition, economic liberty and proportionality guaranteed by the German Constitution. It was contended that the regulation was in breach of the constitution and invalid. The ECJ held that the law deriving from the Treaty could not because of its very nature be overridden by rules of national law. The validity of a community measure could not be affected by allegations that it ran counter to either fundamental rights in the constitution or the principles underlying a constitutional structure.

The European Court of Justice held that a Member State had a duty to give precedence to Community law over earlier or later national legislation and to refuse to apply the offending national legislation even in the absence of an application to set it aside.

In Case 213/89 Factortame [1990] ECR I - 2433 on a reference from the House of Lords the ECJ expanded the principle in Simmenthal (supra) by requiring national courts in a case before them concerning Community law to set aside any rule of national law that precluded them from granting interim relief. The House of Lords [1990] 2 Lloyd's Rep. 365 (H.L.) later granted an interim injunction pending final judgment restraining the Secretary of State from withholding or withdrawing registration of specified shipping vessels pursuant to certain challenged statutory regulations.

Independently of Costa $v$ ENEL (supra), in monist countries, Community law when it conflicts with national law may take precedence over national law. For example, in the Netherlands, which gave Suriname its system of law, provisions in international treaties which bind the state and citizens have direct effect and take precedence over national legislation and even the constitution: see Articles 93 and 94 of the Dutch Constitution. Articles 105 and 106 of the Suriname Constitution are in similar vein.

"Article 105 - The provisions of the agreement mentioned in article 103 which may be directly applicable to anyone shall have this binding effect as from the time of publication.

Article 106 - Legal regulations in force in the Republic of Suriname shall not apply, if this application should be incompatible with provisions that are directly applicable to 
anyone, to agreements entered into either before or after the enactment of the regulations. "

Article 55 of the French Constitution states that treaties and agreements duly ratified "have authority superior to that of laws."

The 1987 Haiti Constitution contains a similar clause in Article 276-2, which provides:

"Once international treaties or agreements are approved and ratified in the manner stipulated by the Constitution, they become part of the legislation of the country and abrogate any laws in conflict with them."

Thus, in the case of the four monist states of the EEC, as in the case of Haiti and Suriname in the Caribbean Community, Community law is and was supreme over national law. By contrast, at the time of Costa v ENEL (supra), in the case of dualist states such as Germany and Italy, international treaties did not enjoy a higher status than national law. An international treaty when transposed into domestic law became like any other law, vulnerable to implied repeal by a later statute.

The effect of this difference of approach between the monist and dualist countries of the EEC Treaty would have been to produce different results in respect of later incompatible legislation. It was in order to ensure that there would be even consistent and uniform application of Community law in the six countries of the EEC that the doctrine of supremacy of Community law was propounded.

In the Caribbean Community in the light of a similar cleavage between monist and dualist Member States and the importance of maintaining uniform and consistent interpretation of the Revised Treaty, the need arises for a doctrine of supremacy in the limited area where Community law and national law overlap. However, there are two major obstacles to the application of the doctrine of supremacy in the Caribbean Community law:

(1) the supreme law clauses of the "common law" constitutions and

(2) the Protocol to the Revised Treaty of 2005 ("the 2005 Protocol”)

The 2005 Protocol provides:

\section{Article I}

\section{Relationship to Constitutional Order}

Insert in the Revised Treaty Article 222 (bis) as follows:

The provisions regarding the original jurisdiction set out in this Chapter shall not be construed to require a Contracting Party to enact legislation that is inconsistent with its constitutional structure or the nature of its legal systems.

This article seems designed to encourage signature, ratification and local incorporation of the Revised Treaty by states. On the other hand, the language of the 2005 Protocol might be construed as a rule of construction for municipal judges that no transposed provision of the Revised Treaty is to be treated as unconstitutional. However, it is unlikely that any municipal court would make an order that the state amend the constitution. At best it would make a declaration of incompatibility with the constitution.

Further, the 2005 Protocol might be construed as stating what the contracting parties always understood that no changes to the constitutional structure or the legal system were intended by the Revised Treaty. The intention of the 2005 Protocol was to deal with the proposition (after Independent Jamaica Council for Human Rights (1988) Ltd. v Marshall-Burnett [2005] 2 AC 356) that a reference under Article 214 of the Revised Treaty to the Caribbean Court of Justice would be a reference to a court that did not enjoy the advantage of entrenchment enshrined in the Jamaica Constitution in respect of superior courts such as the Jamaican Court of Appeal.

While it is true that the Privy Council in the Independent Jamaica Council case was not dealing with the original jurisdiction of the Caribbean Court of Justice, the real issue is whether it is permissible to hive off part of the jurisdiction of a national court to a supposedly unconstitutional court, whatever jurisdiction it purports to exercise. That issue can only be resolved by a reversal of the Independent Jamaica Council case or a finding that a reference by a national court to the Caribbean Court pursuant to Article 214 of the Revised Treaty does not offend the Jamaican Constitution. In any event, the terms of the local incorporation of Article 214 in the Act incorporating the Caribbean Court's original jurisdiction appears to be misconceived since it purports to give power to a public official to seek an advisory opinion from the court, a right reserved only to Member States.

The second difficulty concerning the precedence of Community law arises where there is a conflict with national law and constitutional law in particular, in common law countries. Because of the incorporation of Community law into the national legal systems, national law is always in theory subject to amendment or repeal by a later national law. For that reason, in the United Kingdom the European Communities Act 1972, which adopts the principles of the supremacy of Community law, may in theory be amended or repealed by an Act. Can Community law override the constitution? One possible resolution of the problem is to regard the constitution as a living instrument. On such a reading, a national court may be inclined to interpret the constitution in the light of changing economic, social and cultural realities. Among these realities are the collective aim of Member States for regional economic integration expressed in the Preamble to the Revised Treaty and local incorporations of it and the establishment of a single court, with both a national and a regional jurisdiction for the purpose of achieving 
consistent and uniform interpretation of the Revised Treaty throughout the region.

On the other hand, I would hazard a guess that the Caribbean Court might rule in favour of the precedence of Community law, if only to achieve a result that is uniform as between civil law and common law systems.

\section{GENERAL PRINCIPLES OF LAW: THE IMPACT OF NATIONAL LAW}

As indicated above, the Revised Treaty is a creature of international law, Article 217 provides as follows:

"The Court in exercising its original jurisdiction under Article 211 shall apply such rules of international law as may be applicable."

In the special leave proceedings in TCL $v$ Caribbean Community [2009] CCJ 2, the Caribbean Court referred to Article 38(1) of the Statute of the International Court of Justice, which is generally regarded as having authoritatively stated the sources of international law as:

(a) International conventions, whether general or particular, establishing rules recognised by the contracting parties;

(b) International custom, as evidence of a general practice accepted as law;

(c) General principles of law recognised by civilised nations;

(d) Subject to the provisions of Article 59, judicial decisions and the teachings of the most highly qualified publicists of the various nations, as a subsidiary means for the determination of rules of law.

Reference should also be made to Aust, A, Handbook of International Law, Cambridge University Press, p 6.

It is the application of general principles fashioned by the judges and general principles culled from the national legal systems of Member States to the "new legal order of international law" of the regional treaty that creates Community law as a separate system of law. The general principles of law invented by the judges are tools of interpretation and application for the protection of treaty rights of individuals and entities in the interests of the rule of law. These universal general principles referred to in the ICJ statute are in no way different from those applicable specifically to the Member States of CARICOM or to states party to regional economic agreements.

Recourse to the general principles of law already established in recognised regional courts of justice has the potential to protect and secure treaty rights and obligations. The protection of these rights and obligations would advance economic integration by empowering Community nationals to come before the court to seek enforcement of commitments and undertakings in the Revised Treaty.
The experience of the European Court of Justice indicates that the sources of such general principles of law are the national legal systems of the Member States, the EC Treaty or international agreements to which the Member States subscribe. These general principles of law are used as a means of assessing the validity of acts of Community institutions or to control abuse of their powers and to review the acts of national bodies acting within the sphere of Community law. General principles of law may also be used to fill gaps in Community law. Advocate General M Dutheillet de Lamothe explained that the fundamental principles of national legal systems ... "contribute to forming that philosophical, political and legal substratum common to the Member States from which through case law an unwritten Community law emerges, one of the essential aims of which is precisely to ensure the respect for the fundamental rights of the individual.”

General principles of law may be derived also from international law. The general principle of good faith has been held by the Court of First Instance of the ECJ (now Grand Court of the EU) to give rise to legitimate expectations in Community law: see Opel Austria v Council [1997] ECR II - 39. Further, the very doctrine of direct effect is based on an exception to the principle that states are the proper subjects of international law: see the Advisory Opinion in the Danzig Railway Officials case (1928) PCIJ, Ser B No 15 pp 17-18.

The judges of the ECJ filled gaps in the EC Treaty by having regard to principles of law taken from the Member States. In Cases 7/56 and 37/57 Algera et al $v$ Assembly [1957-58] ECR 39, the European Court referred to the need to fill gaps by recourse to national laws especially rules applicable in the law of individual Member States on the issues it had to decide. Professor Hartley summarises the position as follows:

"When the European Court creates new rules of Community law, it purports to do so on the basis of 'general principles of law.' In theory, these are principles found in all or most legal systems. ... The principles thus 'discovered' by the court are not always found in a majority or even any of the legal systems of the Member States. When it wants to create a new legal rule, the European Court certainly looks at the legal systems of the Member States. However, it does not regard itself as bound to adopt the majority view. Once it has informed itself of possible solutions, it considers itself free to fashion the rule it regards as most appropriate to the needs of the Community.'

The Caribbean Court of Justice arrived at broadly similar conclusions in the special leave application of TCL v Caribbean Community [2009] CCJ 2(OJ) at [41].

"[41] ... This Court may take into account the principles and concepts common to the laws of Member States. The search is for general principles of law common to Member States. It is sufficient if the general principle is widely accepted: see the opinion of Advocate General Sir Gordon 
Slynn in AM \& S Europe Ltd. v Commission and of the ECJ. If the general principle is widely accepted throughout the Community and relevant it may become part of Community law. These are tests that will have to be applied if this Court is asked to strike down the decisions authorizing suspension of the CET on grounds that derive from the domestic law applicable to judicial review in common law jurisdictions".

In this way national law might be introduced and made into a Community blend.

Breach of the judge-made general principles of law may, in the ECJ, lead to declarations of invalidity upon a reference, for example because the breach offended the principle of non-discrimination (Cases 103 and 145/77 Royal Scholten-Honig (Holdings) Ltd $v$ Intervention Board [1978] ECR 3037); or because of a breach of the principle of legitimate expectations (Case 120/86 Mulder v Minister van Landbouw en Visserij [1986] ECR 2321); or because of a breach of the principle of proportionality (Case 181/84 EDF Mann v Intervention Board [1985] ECR 2889).

In the area of remedies two judge-made principles are apparent: the principle of effectiveness and the right to protection of Community rights. In TCL and TCL Guyana Incorporated v Guyana [2009] CCJ 5 (OJ), the Caribbean Court accepted the doctrine of state liability for breach of Community obligations based on these two principles.

The Caribbean Court of Justice has recognized the rule that general principles of law drawn from national legal systems or deriving from the provisions of the Revised Treaty will apply in Community law. It has not used all the ammunition potentially at its disposal since the opportunity has not arisen, but a trend has begun.

\section{CONCLUSIONS}

(1) Regional courts of justice are essentially creations of international law. They continue to exist on the international plane.

(2) Regional courts of justice beget an autonomous legal order which one might describe as Community law. Both the European Court of Justice and the Caribbean Court of Justice have so held.

(3) In Caribbean Community law direct effect Treaty provisions have been mediated into national laws both in the civil law and common law systems. In the common law Member States the Revised Treaty was incorporated into domestic law; in the civil law Member States provisions of their constitutions were complied with to make Community law effective nationally. In the EU legal system treaties and subsidiary legislation have direct effect regardless of whether locally incorporated or not.
(4) Though an unwritten rule, the supremacy of Community Law over national law in the areas covered by the Revised Treaty is the logical consequence of direct effect. However it is not clear whether "common law" national courts would also hold that Community law overrides constitutional law although if one looks at the constitution as a living instrument that result would follow.

(5) In any event, through the preliminary reference procedure, national courts in Europe and the Caribbean may become more involved and participate in the integration process. The national courts in Europe have become instruments for the effective application of Community law and the national courts of the Caribbean may follow suit.

(6) National law contributes to Community law via "the general principles of law" based on those established in the European Union and on the current jurisprudence of the Caribbean Court.

(7) The economic integration treaties constitute an outline to be filled in by judge-made law. Judge-made law constitutes a useful resource for moving forward economic integration. As Craig and de Burca said of the ECJ:

"The ECJ has overall pursued a policy of legal integration, giving substance to an outline Treaty, thereby enhancing the effectiveness of Community law and promoting its integration into national legal systems ..."

(8) What emerges is an amalgam of three separate systems fused into one Community law but governed by the rule of law dispensed by the court.

Kirkham reminds us that:

"... for many writers it was not the Commission that was the real driving force behind the EEC in its formative years but the Court of Justice of the European Community."

It is hoped that the Caribbean Court of Justice would achieve similar success in building and strengthening Caribbean economic integration.

The Hon Mr Justice Rolston F Nelson

Caribbean Court of Justice; former IALS Inns of Court Fellow 